\title{
PHYSIOLOGICAL RESPONSES OF Porphyra haitanesis TO DIFFERENT COPPER AND ZINC CONCENTRATIONS
}

\author{
Ying Xia Li ${ }^{l}$, Suo Zhou ${ }^{l}$, Feng Juan Zhao ${ }^{2}$, Yan Liu ${ }^{3}$, Pan Pan Fan ${ }^{l}$, Guang Ce Wang ${ }^{4 *}$
}

${ }^{1}$ School of Life Science and Technology, Nanyang Normal University (Nanyang, China, 473061)

${ }^{2}$ Department of Biological Sciences, BingZhou University （Bingzhou, China, 256600)

${ }^{3}$ School of Life science, Wuhan University of Science and Technology Zhongnan Brach (Wuhan, China, 430223)

${ }^{4}$ Key Laboratory of Experimental Marine Biology, Institute of Oceanology, Chinese Academy of Sciences (Qingdao, China, 266071)

*Correspoding author: liyx108@163.com

\begin{abstract}
A B S TR A C T
In the present study, several physiological responses of the red marine alga Porphyra haitanesis to elevated concentrations of copper (up to $50 \mu \mathrm{M}$ ) and zinc (up to $100 \mu \mathrm{M}$ ) were investigated. Our results showed that the effects of $\mathrm{Cu}^{2+}$ and $\mathrm{Zn}^{2+}$ on growth, photosynthetic pigments (chlorophylls and carotenoids), phycobiliprotein and metabolism (the fluorescence emission spectra and the activities of photosystem II ) did not follow the same pattern. The relative growth rate was inhibited by different concentrations of $\mathrm{Cu}^{2+}$, and was slightly increased at lower concentrations (up to $10 \mu \mathrm{M}$ ) and inhibited at higher $\mathrm{Zn}^{2+}$ concentrations. On the other hand, the phycoerythrin contents were slightly increased at relatively low concentrations (up to $1 \mu \mathrm{M} \mathrm{Cu}^{2+}$ or $20 \mu \mathrm{M} \mathrm{Zn}^{2+}$ ) and inhibited by high $\mathrm{Cu}^{2+}$ and $\mathrm{Zn}^{2+}$ concentrations. Moreover, photosynthesis and respiration showed an increase in the amount of oxygen exchange in response to relatively low $\mathrm{Cu}^{2+}$ (up to $1 \mu \mathrm{M}$ ) and $\mathrm{Zn}^{2+}$ concentrations (up to $10 \mu \mathrm{M}$ ), and a reduction to relatively high $\mathrm{Cu}^{2+}$ and $\mathrm{Zn}^{2+}$ concentrations. Oxygen evolution was more sensitive than oxygen uptake to $\mathrm{Cu}^{2+}$ and $\mathrm{Zn}^{2+}$. In addition, the photoreductive activities and fluorescence emission of photosystem II (PS II) were enhanced by lower concentrations of $\mathrm{Cu}^{2+}$ (up to $0.1 \mu \mathrm{M}$ ) and $\mathrm{Zn}^{2+}$ (up to $10 \mu \mathrm{M}$ ) and inhibited by higher concentrations. Furthermore, the intensity of chlorophyll a fluorescence and the active PSII reaction centers followed a similar pattern in response to elevated concentrations of $\mathrm{Cu}^{2+}$ and $\mathrm{Zn}^{2+}$. These results suggest that lower concentrations of $\mathrm{Cu}^{2+}$ and $\mathrm{Zn}^{2+}$ affected the metabolism of $P$. haitanesis, which was inhibited by higher concentrations of these metals.
\end{abstract}

\section{RESUMO}

No presente estudo foram investigadas as respostas fisiológicas da alga vermelha Porphyra haitanesis às elevadas concentrações de cobre (acima de $50 \mu \mathrm{M}$ ) e de zinco (acima de $100 \mu \mathrm{M}$ ). Os resultados mostram que os efeitos de $\mathrm{Cu}^{2+}$ e $\mathrm{Zn}^{2+}$ sobre o crescimento, pigmentos fotossintéticos (clorofilas e carotenóides), ficobiliproteína e metabolismo (o espectro de emissão de fluorescência e as atividades do fotossistema) não seguem o mesmo padrão. A taxa de crescimento relativo foi inibida por diferentes concentrações de $\mathrm{Cu}^{2+}$ e, em presença de $\mathrm{Zn}^{2+}$, aumentou ligeiramente em baixas concentrações (abaixo de $10 \mu \mathrm{M}$ ) e foi inibida em altas concentrações. Por outro lado, os teores de ficoeritrina apresentaram leve aumento em concentrações relativamente baixas de $\mathrm{Cu}^{2+} \mathrm{e}$ $\mathrm{Zn}^{2+}$ (até $1 \mu \mathrm{M} \mathrm{Cu}^{2+}$ e até $20 \mu \mathrm{M} \mathrm{Zn}^{2+}$, respectivamente) e foram inibidas por altas concentrações. Além disso, tanto a fotossíntese quanto a respiração mostraram aumento nas trocas de oxigênio em resposta às concentrações relativamente baixas de $\mathrm{Cu}^{2+}$ (até $1 \mu \mathrm{M}$ ) e de $\mathrm{Zn}^{2+}$ (até $10 \mu \mathrm{M}$ ), além da redução em concentrações relativamente altas desses metais. Adicionalmente, as atividades fotoredutoras e as emissões de fluorescência do fotossistema II (PSII) foram incrementadas em baixas concentrações de $\mathrm{Cu}^{2+}$ (até $\left.0,1 \mu \mathrm{M}\right)$ e de $\mathrm{Zn}^{2+}$ (até $\left.10 \mu \mathrm{M}\right)$ e inibidas por altas concentrações. Desta forma, a intensidade da fluorescência da clorofila-a e dos centros de reação ativa PSII seguiram um padrão semelhante em resposta às elevadas concentrações de $\mathrm{Cu}^{2+}$ e $\mathrm{Zn}^{2+}$. Esses resultados sugerem que baixas concentrações de $\mathrm{Cu}^{2+}$ e $\mathrm{Zn}^{2+}$ afetam o metabolismo de $P$. haitanesis, que se torna inibido por altas concentrações desses metais.

Descriptors: Porphyra haitanesis, Copper, Zinc, Photosystem II. Descritores: Porphyra haitanesis, Cobre, Zinco, Fotossistema II. 


\section{INTRODUCTION}

Among the modern pollutants interfering with photosynthetic organism metabolism, heavy metals are one of the most common nonbiodegradable pollutants reported at elevated concentration in many parts of the world (MALLICK; RAI, 2001). Mining of metals, geo- chemical structure, industrial effluents and wastes, create a potential source of heavy metal pollution in the aquatic environment (GUMGUM et al., 1994). The toxic metals can be divided into two groups: essential and non-essential (REDDY; PRASAD, 1990). The first group includes $\mathrm{Pb}, \mathrm{Hg}, \mathrm{Ur}$, $\mathrm{Ag}$ and $\mathrm{Be}$, all of them are highly poisonous without any nutritional value (INTHORN, 2001). The second group consists of metals such as that are essential as nutritional requirements at trace amount for many organisms but are toxic at high level. This group consists of $\mathrm{Fe}, \mathrm{Mn}, \mathrm{Cu}, \mathrm{Mo}, \mathrm{Zn}$ and $\mathrm{Co}$ (SOLISIO et al., 2008).

Copper is the most commonly used toxic heavy metal for industrial purposes and its presence in aquatic system sarises from both naturally occurring and man-made origin (PERALES-VELA et al., 2007). Copper is ubiquitous in the environment. Various sources of copper $(\mathrm{Cu})$, including industrial and domestic wastes, agricultural practices, copper marine drainage, copper-based pesticides, and antifouling paints, have leaded to a clear increase in $\mathrm{Cu}$ concentrations in aquatic environments (CALLOW; CALLOW, 2002). $\mathrm{Cu}$ is essential for macroalgae, which participates in important biological reactions as an enzymatic cofactor and electron carrier in the photosynthetic and respiratory processes at low concentrations (ANDRADE et al., 2004). It can interfere with numerous physiological processes and is considered to be potentially cytotoxic when applied in amounts higher than its particularly level, and its sensitivity varies among different macroalgae (FERNANDES; HENRIQUES, 1991; CHANG; SIBLEY, 1993). The toxicity of copper is mainly related to free ions and is a potent inhibitor of photosynthesis in macroalgae (KÜPPER et al., 2002).

Zinc ( $\mathrm{Zn})$ is a well- known essential micronutrient for normal growth of algae, which is widely required in many biological processes and is present in nearly 300 enzymes that perform many different metabolic functions (VALLEE; AULD, 1990). It has the adverse effects of this non- redox active metal as oxidative stress factor when in excess (CHAOUI et al., 1997).

Porphyra is one of the most important marine macroalgae with respect to its global distribution and economical importance, which is also important for aquatic ecosystems and as a food, biochemicals, and pharmaceuticals. Porphyra haitanensis Chang et Zheng, an intertidal red alga with high economic value, only habits and widely cultured in south of China (GAO et al., 2004a). Many studies have been devoted to the interference of copper and zinc with a number of physiological processes, while there is a general lack of information to follow and correlate both these metal induced responses in macroalgae. The aim of the present study was to investigate the effects of copper and zinc on growth, photosynthesis, pigments, proteins, fluorescence intensities and PSII activities of $P$. haitanesis in response to elevated concentrations of copper and zinc.

\section{Material and Method}

\section{Alga Harvest}

The gametophytic blade of Porphyra haitanesis Chang et Zheng was collected from the seashore of Xiamen, China. Discs of approximately $1.2 \mathrm{~cm}$ in diameter were cut from the gametophytic blade of $P$. haitanesis and incubated in nutritional seawater in which $0.1 \mathrm{M} \mathrm{NaNO} \mathrm{Nan}_{3}$ and $0.1 \mathrm{M}$ $\mathrm{NH}_{4} \mathrm{H}_{2} \mathrm{PO}_{4}$ was added. Plants were grown at $18^{\circ} \mathrm{C}$ in 16: 8 light and dark cycles with $50 \mu \mathrm{mol}$ photons $\mathrm{m}^{-2}$ $\mathrm{s}^{-1}$ provided by cool- white fluorescent bulbs. Experiments were conducted in $500 \mathrm{ml}$ flasks that had been autoclaved at $121^{\circ} \mathrm{C}$ for $20 \mathrm{~min}$. The copper and zinc stock solutions were prepared from their analytical grade metallic salts (i.e. $\mathrm{CuSO}_{4} \cdot 5 \mathrm{H}_{2} \mathrm{O}$ and $\mathrm{ZnSO}_{4} .5 \mathrm{H}_{2} \mathrm{O}$, respectively) dissolved in deionized water. $\mathrm{Cu}^{2+}$ and $\mathrm{Zn}^{2+}$ solutions in the range $0-50 \mu \mathrm{M}$ and $0-100 \mu \mathrm{M}$, respectively were prepared by the dilution of a concentrated stock solution. Algal samples were taken after seven days of incubation.

\section{Growth Rate}

The relative growth rate (R), expressed as $\%$ day $^{-1}$, was computed from the following expression (KAIN, 1987):

$\mathrm{R}=\left(\operatorname{In} \mathrm{a}_{\mathrm{t}}-\operatorname{In} \mathrm{a}_{\mathrm{o}}\right) / \mathrm{t}$

where $a_{t}$ is the area measured at time ( $\left.t\right)$ in days and $a_{0}$ is the area at the initial time. Three replicates were taken for each treatment. Disc area was determined using an image analysis software.

\section{Oxygen Exchange}

The oxygen exchange was measured with a commercial Clark-type oxygen electrode (Hansatech Instruments Ltd., England), at $18^{\circ} \mathrm{C}$. P. haitanesis fronds were placed in an electrode chamber containing bicarbonate buffer, $\mathrm{pH} 7.6$, to provide constant $\mathrm{CO}_{2}$ concentration in the medium. The changes in oxygen concentration in the darkness and in the light $(50 \mu \mathrm{mol}$ $\mathrm{m}^{-2} \mathrm{~s}^{-1}$ illumination) were recorded under constant stirring of the sample. 
Photosynthetic Pigments

Two discs of approximately $10-20 \mathrm{mg}$ fresh weight (FW) per sample were extracted in $80 \%$ acetone at $4^{\circ} \mathrm{C}$ in darkness. The resulting suspension was centrifuged at $10,000 \mathrm{~g}$ for $5 \mathrm{~min}$. The content of Chl $a$ and carotenoids were determined as described by Kursar and Alberte (1983).

\section{Phycobiliprotein Content}

One tenth of $P$. haitanesis gametophytic blade was extracted in $2 \mathrm{ml}$ of $0.1 \mathrm{M}$ Na-phosphate buffer $\left(\mathrm{pH} \mathrm{7.0)}\right.$ at $4^{\circ} \mathrm{C}$ in darkness.. The resulting suspension was centrifuged at $10,000 \mathrm{~g}$ for $5 \mathrm{~min}$. The supernatant was collected for in vivo absorption spectra measurement at room temperature. The contents of phycoerythrin (PE), phycocyanin (PC), and allophycocyanin (APC) in the cell extracts of $P$. haitanesis were made using the extinction coefficients, as described by Kursar et al. (1983).

\section{Isolation of Photosystem II}

The photosystem II (PS II) was isolated according to the method of Gao et al. (2004b). The fragmented alga was centrifuged at 5,000 g for $5 \mathrm{~min}$ to remove large debris. The supernatant was collected and centrifuged at 140,000 g (Beckman L8-80, Ti- 45 rotor) for $1 \mathrm{~h}$ at $4^{\circ} \mathrm{C}$. The resulting pellet was suspended and centrifuged at $140,000 \mathrm{~g}$ on the sucrose density gradient consisting of $60 \%, 50 \%, 40 \%, 30 \%$ and $20 \%(\mathrm{w} / \mathrm{v})$ sucrose in proportions of $1: 1: 1: 1: 1$ (Beckman L8-80, Sw-40 rotor) for $3.5 \mathrm{~h}$ at $4{ }^{\circ} \mathrm{C}$. The thylakoid membrane was isolated in $50-60 \%$ sucrose layer, and treated with SDS, then loaded onto the sucrose density gradient consisting of $60 \%, 50 \%, 40 \%$, $30 \%, 20 \%, 15 \%, 10 \%(\mathrm{w} / \mathrm{v})$ sucrose in proportions of 1:1:1:1:1:1:1 containing $0.2 \%$ SDS, and ultracentrifuged at $140,000 \mathrm{~g}$ for $15 \mathrm{~h}$ at $4^{\circ} \mathrm{C}$. The band in $40 \%$ sucrose layer was PSII.

\section{The Activities of Photosystem II}

The DCIP (2, 6- dichloroindophenol) photoreduction rates of potosystem II (PS II) obtained from the sucrose density gradient ultracentrifugation, either with or without added artificial electron donor DPC (1,5-diphenylcarbazide), were measured spectrophotometrically at $580 \mathrm{~nm}\left(12.9 \mathrm{mM}^{-1} \cdot \mathrm{cm}^{-1}\right)$, in a medium containing $40 \mu \mathrm{M}$ DCIP and $30 \mathrm{mM}$ MES-NaOH (pH 6.8). The concentration of samples was equivalent to $10 \mu \mathrm{g} \mathrm{Chl} a . \mathrm{mL}^{-1}$.

The fluorescence emission spectra of PSII were recorded at room temperature by a Hitachi 850 fluorescence spectrophotometer. The concentrations of samples were equivalent to $10 \mu \mathrm{g} \mathrm{Chl} a \cdot \mathrm{ml}^{-1}$.
Statistical Analysis

All data were presented as the mean $\pm \operatorname{SD}(n=3)$. The statistical analyses were performed using SAS software. The data were analyzed using Duncan's multiple range test at the $5 \%$ level.

$$
\begin{gathered}
\text { R E S U L T } \\
\text { Effect of } \mathrm{Cu}^{2+} \text { and } \mathrm{Zn}^{2+} \text { on Growth }
\end{gathered}
$$

The relative growth rates of $P$. haitanesis decreased as $\mathrm{Cu}^{2+}$ concentration increased in the culture medium. Inhibition of relative growth rates was not significant at $0.1 \mu \mathrm{M} \mathrm{Cu}^{2+}$, whereas at $1 \mu \mathrm{M}$, a reduction in relative growth was apparent. At the end of the experiment, the relative growth rate in the control was $1.2 \%$ day $^{-1}$ and was $0.05 \%$ day $^{-1}$ at 50 $\mu \mathrm{M} \mathrm{Cu}{ }^{2+}$ (Fig. 1a). On the other hand, lower concentrations $(0.1$ and $1 \mu \mathrm{M})$ of $\mathrm{Zn}^{2+}$ led to an increase in the relative growth of $P$. haitanesis. Thus, a growth stimulation of $7.7 \%$ and $1.7 \%$ was observed in the cultures treated with 0.1 and $1 \mu \mathrm{M} \mathrm{Zn}^{2+}$, respectively. Higher concentrations (20, 50 and 100 $\mu \mathrm{M})$ exerted a progressive inhibitory effect on algal growth (Fig. 1b).

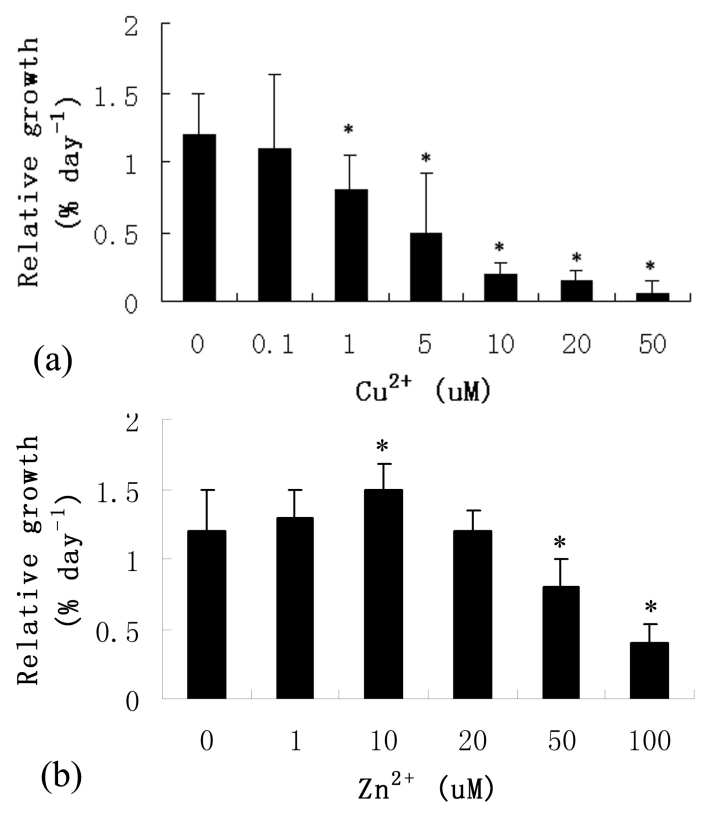

Fig. 1. Effect of $\mathrm{Cu}^{2+}$ (a) and $\mathrm{Zn}^{2+}$ (b) on relative growth rates $\left(\%\right.$ day $\left.^{-1}\right)$ in Porphyra haitanesis following metal exposure for $168 \mathrm{~h}$. Significant levels between control and treatments are indicated by asterisks $(\mathrm{P}<0.05)$. 
Effect of $\mathrm{Cu}^{2+}$ and $\mathrm{Zn}^{2+}$ on Photosynthesis and Respiration

Metabolic rates were stimulated at lower $\mathrm{Cu}^{2+}$ and $\mathrm{Zn}^{2+}$ concentrations and inhibited at higher $\mathrm{Cu}^{2+}$ and $\mathrm{Zn}^{2+}$ concentrations (Fig. 2). Photosynthetic oxygen evolution reached a maximum at $1 \mu \mathrm{M} \mathrm{Cu}{ }^{2+}$ and was $68.5 \%$ higher than the control. At $5 \mu \mathrm{M} \mathrm{Cu}^{2+}$, the photosynthetic rates decreased greatly and at $50 \mu \mathrm{M}$, which was the highest concentration tested, the photosynthetic process was inhibited by $67.6 \%$ compared to the control. Respiratory rates increased to a maximum at $5 \mu \mathrm{M} \mathrm{Cu}^{2+}$ and were $108 \%$ higher than that of the control, then decreased with increasing $\mathrm{Cu}^{2+}$ concentration (a). On the other hand, lower concentrations of $\mathrm{Zn}^{2+}(1$ and $10 \mu \mathrm{M})$ gradually increased oxygen evolution and oxygen uptake (b). A considerable decrease in oxygen evolution was observed at higher concentrations. Oxygen evolution was reduced by $27.8,50$ and $76.9 \%$ compared to the control when treated with 20,50 and $100 \mu \mathrm{M} \mathrm{Zn}{ }^{2+}$, respectively. At the same time, oxygen uptake was reduced by $21.2,34.6$ and $19.2 \%$ compared with the control when treated with 20,50 and $100 \mu \mathrm{M} \mathrm{Zn}^{2+}$, respectively.

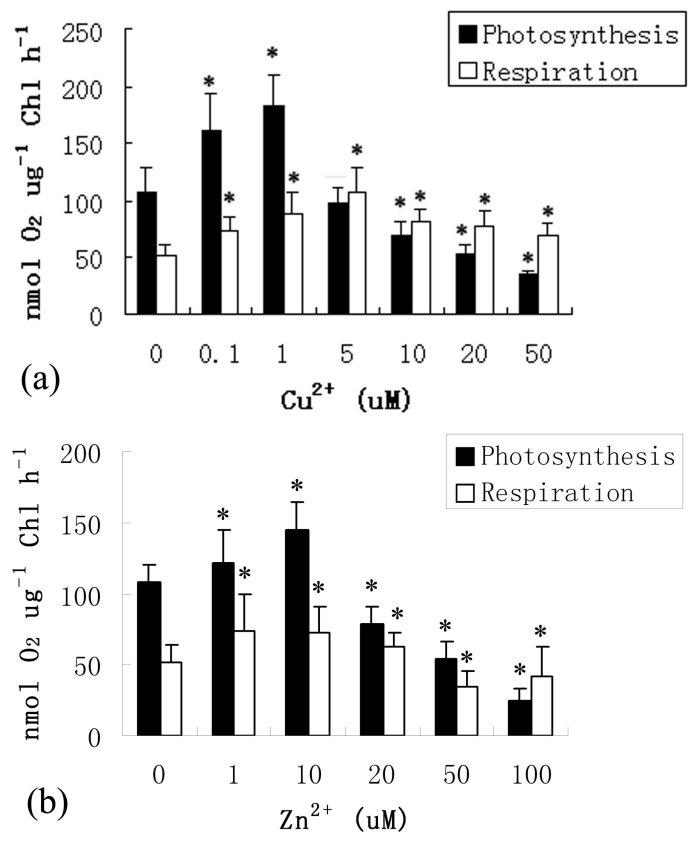

Fig. 2. Effect of $\mathrm{Cu}^{2+}$ (a) and $\mathrm{Zn}^{2+}$ (b) on the $\mathrm{O}_{2}$ evolution (photosynthesis) and $\mathrm{O}_{2}$ consumption (respiration) in Porphyra haitanesis after $168 \mathrm{~h}$ of metal treatment. Significant levels between control and treatments are indicated by asterisks $(\mathrm{P}<0.05)$.
Effect of $\mathrm{Cu}^{2+}$ and $\mathrm{Zn}^{2+}$ on Photosynthetic Pigment

As shown in Figure 3a, the application of 0.1 and $1 \mu \mathrm{M} \mathrm{Cu}^{2+}$ increased chlorophyll a (Chl $a$ ) content by 7.3 and $39.1 \%$ above the control level, respectively. However, Chl $a$ content decreased significantly with increased $\mathrm{Cu}^{2+}$ concentrations. Thus, 5, 10, 20, $50 \mu \mathrm{M}$ $\mathrm{Cu}^{2+}$ led to a reduction of $7.3,21.8,36.4$ and $58.2 \%$ compared with the control level, respectively. Lower $\mathrm{Cu}^{2+}$ concentrations $(0.1$ and $1 \mu \mathrm{M})$ stimulated the biosynthesis of carotenoids. Whereas, higher $\mathrm{Cu}^{2+}$ concentrations resulted in lower reductions in carotenoids when compared with $\mathrm{Chl} a$. The magnitude of this reduction was $56.5 \%$ for cultures treated with $50 \mu \mathrm{M} \mathrm{Cu}^{2+}$ (Fig. 3a). On the other hand, application of 1,10 and $20 \mu \mathrm{M} \mathrm{Zn^{2+ }}$ stimulated an increase in Chl $a$ content, and a pronounced increase in carotenoids was only achieved in $10 \mu \mathrm{M} \mathrm{Zn}^{2+}$. The application of 50 and $100 \mu \mathrm{M} \mathrm{Zn}{ }^{2+}$ resulted in an apparent decrease in Chl $a$ and carotenoids (Fig. 3b).
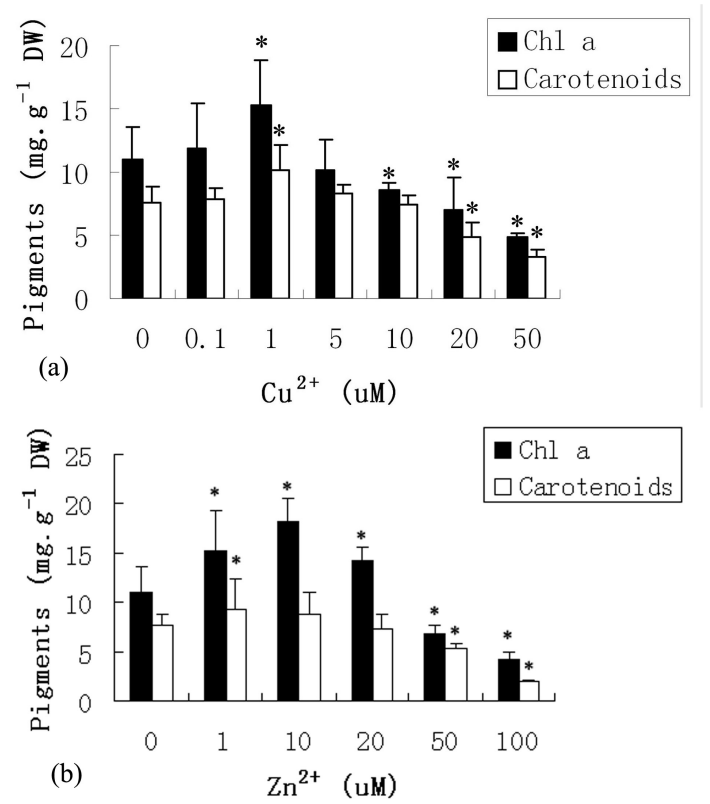

Fig. 3. Effect of $\mathrm{Cu}^{2+}$ (a) and $\mathrm{Zn}^{2+}$ (b) on the content of Chl $a$ and carotenoids in Porphyra haitanesis after $168 \mathrm{~h}$ of metal treatment. Significant levels between control and treatments are indicated by asterisks $(\mathrm{P}<0.05)$.

\section{Effect of $\mathrm{Cu}^{2+}$ and $\mathrm{Zn}^{2+}$ on Phycobiliprotein}

As shown in Figure 4, lower concentrations of $\mathrm{Cu}^{2+}$ and $\mathrm{Zn}^{2+}$ stimulated the biosynthesis of PE, PC and APC, and higher concentration of $\mathrm{Cu}^{2+}$ and $\mathrm{Zn}^{2+}$ inhibited the biosynthesis of PE, PC and APC. The 
contents of PE and APC were maximal at $1 \mu \mathrm{M} \mathrm{Cu}^{2+}$, and $\mathrm{PC}$ was maximal at $0.1 \mu \mathrm{M} \mathrm{Cu}{ }^{2+}$. Maximum reductions in $\mathrm{PE}(54.4 \%)$, $\mathrm{PC}(41.6 \%)$ and $\mathrm{APC}$ $(44.8 \%)$ were recorded at $50 \mu \mathrm{M} \mathrm{Cu}^{2+}$ (a). Increases in PE, PC and APC were 34.2, 38.2 and $8.6 \%$ at $20 \mu \mathrm{M}$ $\mathrm{Zn}^{2+}$, respectively. Maximum reductions in $\mathrm{PE}$ (46.7\%), PC (43.8\%) and APC (39.7\%) were recorded at $100 \mu \mathrm{M} \mathrm{Zn}^{2+}$ (b).

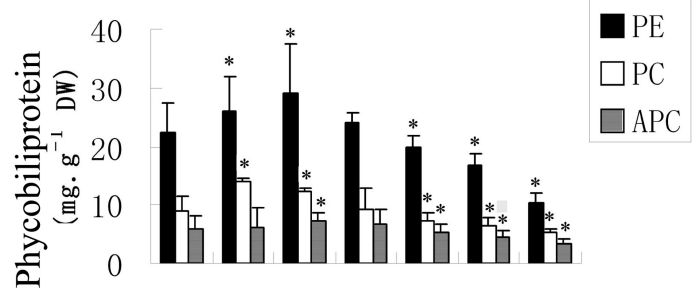

(a)

$\begin{array}{lllllll}0 & 0.1 & 1 & 5 & 10 & 20 & 50\end{array}$

$\mathrm{Cu}^{2+}(\mathrm{uM})$

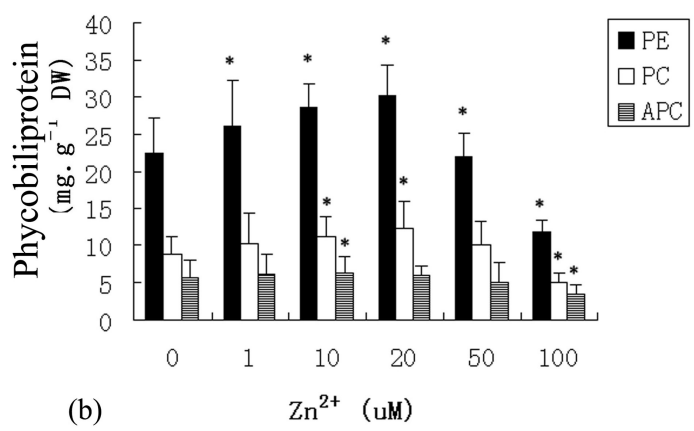

Fig. 4. Effect of $\mathrm{Cu}^{2+}$ (a) and $\mathrm{Zn}^{2+}$ (b) on phycobiliprotein in Porphyra haitanesis after $168 \mathrm{~h}$ of metal treatment. Significant levels between control and treatments are indicated by asterisks $(\mathrm{P}<0.05)$.

\section{Effect of $\mathrm{Cu}^{2+}$ and $\mathrm{Zn}^{2+}$ on PSII activities}

Figure 5 shows that the application of 0.1 and $1 \mu \mathrm{M} \mathrm{Cu}^{2+}$ increased the photoreduction activities of PSII, with values of 38.5 and $21.8 \%$ above the control level, respectively. Higher concentrations of $\mathrm{Cu}^{2+}$ resulted in a pronounced reduction in the photoreduction activities of PSII. Maximum reduction was recorded in the culture treated with $50 \mu \mathrm{M} \mathrm{Cu}^{2+}$, with a value of $87.1 \%$ below the control level (a). On the other hand, the application of 1,10 and $20 \mu \mathrm{M}$ $\mathrm{Zn}^{2+}$ led to a $45.4,84.6$ and $50.8 \%$ increase above the control value, and the application of 50 and $100 \mu \mathrm{M}$ $\mathrm{Zn}^{2+}$ resulted in a pronounced reduction in the photoreduction activities of PSII(b).

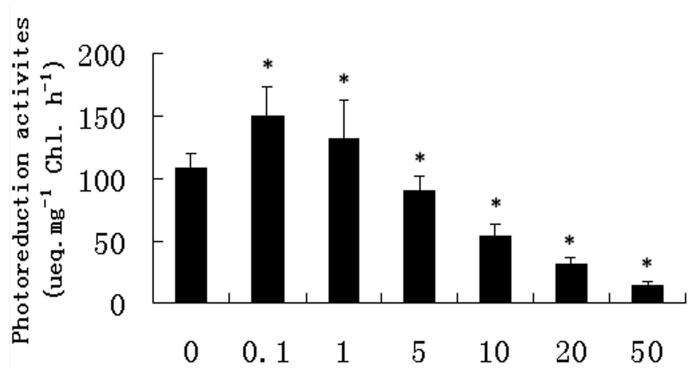

(a)

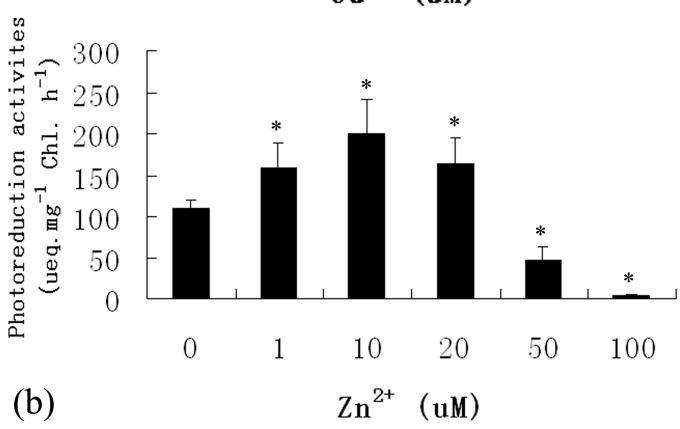

Fig. 5. Effect of $\mathrm{Cu}^{2+}$ (a) and $\mathrm{Zn}^{2+}$ (b) on the PSII activities in Porphyra haitanesis after $168 \mathrm{~h}$ of metal treatment. Significant levels between control and treatments are indicated by asterisks $(\mathrm{P}<0.05)$.

As shown in Figure 6, lower concentrations of $\mathrm{Cu}^{2+}(0.1 \mu \mathrm{M})$ and $\mathrm{Zn}^{2+}(1$ and $10 \mu \mathrm{M})$ enhanced the fluorescence emission of PSII, and higher concentrations of $\mathrm{Cu}^{2+}(1,5,10,20$ and $50 \mu \mathrm{M})$ and $\mathrm{Zn}^{2+}(20,50$ and $100 \mu \mathrm{M})$ inhibited the fluorescence emission of PSII.
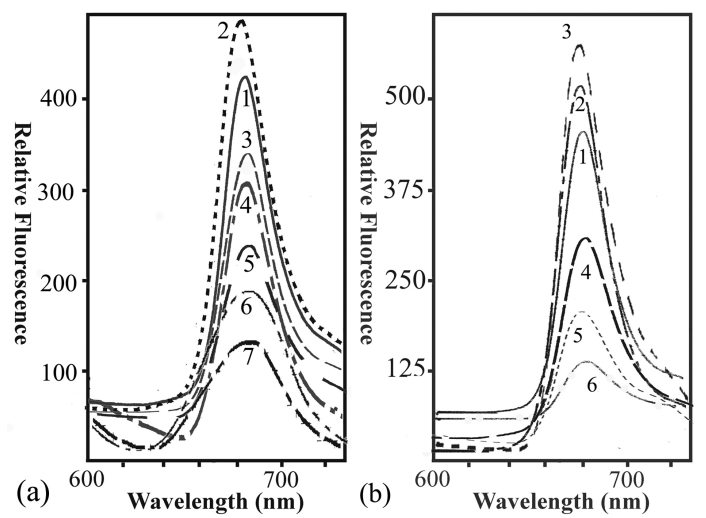

Fig. 6. Effect of $\mathrm{Cu}^{2+}$ (a) and $\mathrm{Zn}^{2+}$ (b) on the fluorescence emission spectra of Chl $a$ in Porphyra haitanesis after $168 \mathrm{~h}$ of metal treatment. a: (1) control, (2) $0.1 \mu \mathrm{M} \mathrm{Cu}^{2+}$, (2) $1 \mu \mathrm{M}$ $\mathrm{Cu}^{2+}$, (2) $5 \mu \mathrm{M} \mathrm{Cu}^{2+}$, (2) $10 \mu \mathrm{M} \mathrm{Cu}^{2+}$, (2) $20 \mu \mathrm{M} \mathrm{Cu}^{2+}$, (2) 50 $\mu \mathrm{M} \mathrm{Cu}^{2+}$; b: (1) control, (2) $1 \mu \mathrm{M} \mathrm{Zn}^{2+}$, (3) $10 \mu \mathrm{M} \mathrm{Zn}^{2+}$, (4) $20 \mu \mathrm{M} \mathrm{Zn}^{2+}$, (5) $50 \mu \mathrm{M} \mathrm{Zn}{ }^{2+}$, (6) $100 \mu \mathrm{M} \mathrm{Zn}^{2+}$. 


\section{Discussion}

All the studied parameters with the exception of relative growth rate, namely, pigment content, oxygen evolution, PS II activities and fluorescence intensities of $P$. haitanesis, were promoted in lower concentrations (up to $0.1 \mu \mathrm{M} \mathrm{Cu}^{2+}$ or $10 \mu \mathrm{M} \mathrm{Zn}^{2+}$ ) and inhibited in higher concentrations of $\mathrm{Cu}^{2+}$ (greater than $5 \mu \mathrm{M}$ ) and $\mathrm{Zn}^{2+}$ (greater than $50 \mu \mathrm{M}$ ), indicating that $\mathrm{Cu}^{2+}$ and $\mathrm{Zn}^{2+}$ are essential nutritional requirements, while excess copper and zinc might interfere with several aspects of plant biochemistry including photosynthesis, pigment synthesis, PS II activities and photosynthetic electron transport.

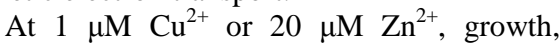
photosynthetic pigment, photosynthesis, PS II activities and electron transport showed different sensitivities. The reason for this may be due to the inhibition of different enzymes involved in a given process or induction of enzymes which can be beneficial or detrimental to a process or pathway in the cell.

Growth decreased as $\mathrm{Cu}^{2+}$ concentration increased in the culture, a similar phenomenon was observed in Schenedemus incrassatus (PERALES-VELA et al., 2007). The effect of $\mathrm{Cu}^{2+}$ on algal growth has been attributed to a massive failure of many cellular processes (FERNANDES; HENRIQUES, 1991). It is well known that $\mathrm{Cu}^{2+}$ has toxic effects on chromosomal morphology and the mitosis cycle (JIANG et al., 2001). In this study, algal growth was more sensitive to $\mathrm{Cu}^{2+}$ than metabolism. The reason for this may be that growth is the conclusion of photosynthetic processes including correct electromagnetic energy absorption which is then changed into chemical energy and the efficient utilization of this chemical energy for $\mathrm{CO}_{2}$ fixation (PERALES-VELA et al., 2007). These cellular processes have different sensitivities to different heavy metals, thus growth of $P$. haitanesis showed different sensitivities to $\mathrm{Cu}^{2+}$ and $\mathrm{Zn}^{2+}$

Three reasons ma bye responsible for the inhibitory effect on Chl $a$ and carotenoids seen in excess $\mathrm{Cu}^{2+}$ and $\mathrm{Zn}^{2+}$ : Firstly, $\mathrm{Cu}^{2+}$ or $\mathrm{Zn}^{2+}$ probably induce production of reactive oxygen species and inhibit the reductive steps in the biosynthesis pathway of these pigments (CLIJSTERS et al., 1999). Secondly, they can directly destroy the structure and function of chloroplast by binding with SH group of enzyme and overall chlorophyll biosynthesis (SINGH, 1995). Lastly. They may activate pigment enzyme and accelerate the decomposition of pigment (HOU et al., 2007). Moreover, carotenoids appeared to be more resistant to $\mathrm{Cu}^{2+}$ and $\mathrm{Zn}^{2+}$ phytotoxicity than $\mathrm{Chl} a$ because the change in Chl $a$ was apparent compared to that of carotenoids.
The photosynthesis and respiration results showed that the photosynthetic process was still active in samples following treatment with $1 \mu \mathrm{M} \mathrm{Cu}^{2+}$ and 50 $\mu \mathrm{M} \mathrm{Zn}^{2+}$. However, negative results for the $5 \mu \mathrm{M} \mathrm{Cu}^{2+}$ and $100 \mu \mathrm{M} \mathrm{Zn}^{2+}$ treatments indicated that consumption of oxygen during respiration was higher than that produced by photosynthesis, confirming the damage to metabolism caused by $\mathrm{Cu}^{2+}$ and $\mathrm{Zn}^{2+}$. The significantly reduced oxygen evolution parameters in $P$. haitanesis were correlated with the relative decrease in $\mathrm{Chl} a$ concentrations at $10 \mu \mathrm{M} \mathrm{Cu}^{2+}$. This was in agreement with the results of Andrade et al. (2004). Moreover, a higher concentration of $\mathrm{Zn}^{2+}(20 \mu \mathrm{M})$ also decreased photosynthesis and $\mathrm{Chl} a$ content. Above results indicated that $\mathrm{Cu}^{2+}$ and $\mathrm{Zn}^{2+}$ also exerts their toxicity on photosynthesis mainly due to the loss of Chl a. Moreover, increased generation of reactive oxygen species induced by these metals can induce membrane lipid peroxidation and increase unstaching of thylakoids (CLIJSTERS et al., 1999).

The changes of Chl $a$ fluorescence and PSII activites showed the same pattern indicating that changes in room temperature $\mathrm{Chl} a$ fluorescence intensity are intimately association with PS $\square$ activity and reflect the primary acceptor of PSII (RENGER; SCHREIBER, 1986). In this study, marked decreases in chlorophyll fluorescence and PSII activities were observed in response to exposure to higher concentrations of $\mathrm{Cu}^{2+}$ and $\mathrm{Zn}^{2+}$ due to the substitution of $\mathrm{Mg}^{2+}$ in Chl $a$ molecules bound to the PS II reaction center (KÜPPER et al., 1996, 1998, 2002).

\section{ACKNOWLEDGEMENT}

The work was supported by the key subject of Biochemistry and molecular biology in Henan province.

\section{REFERENCE}

ANDRADE, L. R.; FARINA, M.; FILHO, A. M. G. Effects of copper on Enteromorpha flexuosa (Chlorophyta) in vitro. Ecotoxicol. Environ. Safe., v. 58 p.117- 125, 2004.

CALLOW, M. E.; CALLOW, J. Marine biofouling: a sticking problem. Biologist., v. 49, n. 1, p. 1-5, 2002.

CHANG, C.; SIBLEY, T. H. Accumulation and transfer of copper by Oocystis pusilla. Bull environ. Contamin. Toxicol., v. 50, p. 689- 695, 1993.

CHAOUI, A.; MAZHOUDI, S.; GHORBAL, M. H.; ELFERJANI, E. Cadmium and zinc induction of lipid peroxidation and effects on antioxidant enzyme activities in bean (Phaseolus vulgaris L). Pl. Sci., v. 127, p. 139147, 1997.

CLIJSTER, H.; CUYPERS, A., VANGRONSVELD, J.; Physiological response to heavy metals in higher plants defence against oxidative stress. Z. Naturf., v. 54, p. 730-734. 1999. 
FERNANDES, J.C.; HENRIQUES, F. S. Biochemical, physiological and structural effect of excess copper in plants. Bot. Rev., v. 57, p. 246- 273, 1991.

GAO, K. S.; YAN, J. I.; TANAKA, J. Quantitative evaluation of wind effect during emersion on Porhpyra haitanensis (Rhodophyta), a farmed species in southern China. Fisheries Sci., v. 70, p. 710- 712, 2004a.

GAO, Z. Q.; WANG, G. C.; Tseng, C. K. Isolation and characterization of photosystemII of Porphyra yezoensis Udea. Acta Biochim. Biophys. Sinica., v. 36, p. 780$785,2004 \mathrm{~b}$

GUMGUM, B.; UNLU, E.; TEZ, Z.; GULSUN, Z. Heavy metal pollution in water, sediment and fish from the Tiger River in Turkey. Chemosphere., v. 29, n. 1, p. 111116, 1994.

HOU, W. H.; SONG, G. L.; WANG, Q. H.; CHANG, C. C. Effects of copper and cadmium on heavy metal polluted waterbody restoration by duckweed (Lemna minor). Pl. Physiol. Biochem., v. 45, p. 2-69, 2007.

INTHORN, D. Removal of heavy metal by using microalgae. In: KOJIMA, H.; LEE, Y. K. (Ed.). Photosynthetic microorganisms in environmental Biotechnology. Springer- Verlag Hong Kong., 2001. p. 111- 169.

JIANG, W.; LIU, D.; LIU, X. Effects of copper on root growth, cell division, and nucleolus of Zea mays. Biologia Pl., v. 44, p. 105- 109, 2001.

KAIN, J.M. Seasonal growth and photoinhibition in Plocamium cartilagineum (Rhodophyta) of the Isle of Man. Phycologia., v. 26, p. 88- 99, 1987.

KÜPPER, H.; KÜPPER, F.; SPELLER, M. Environmental relevance of heavy metal- substituted chlorophylls using the example of water plants. J. expl Bot., v 47, p. 259-266, 1996.

KÜPPER,H.; KÜPPER, F.; SPILLER, M. In situ detection of heavy metal substituted chlorophylls in water plants. Photosynth. Res., v. 58, p. 123-133. 1998.

KÜPPER, H.; ŠETLÍK, I.; SPILLER, M.; KÜPPER, F. C.; PRÁŠ́IL, O. Heavy metal-induced inhibition of photosynthesis: targets of in vivo heavy metal chlorophyll formation. J. Phycol., v. 38, p. 429- 441, 2002.
KURSAR, T.; ALBERTE, R. S. Photosynthetic unit organization in a red alga. Pl. Physiol., v. 72, p. 409- 414, 1983.

KURSAR, T. A.; MEER, J. ALBERTE, R. S. Light-harvesting system of the red alga Gracilaria tikvahiae. I. Biochemical analyses of pigment mutations. Pl. Physiol., v. 73, n. 2, p.353- 360, 1983.

MALLICK, N.; RAI, L. C. Physiological responses of non-vascular plants to heavy metals. In: PRASAD, M. N. V.; STRZALKA, K. (Ed.). Physiology and Biochemistry of metal toxicity and tolerance in plants. The Netherlands: Kluwer, 2001. p. 111-147.

PERALES-VELA, H. V.; GONZÁLEZ -MORENO, S.; MONTES-HORCASITAS, C.; CAŇIZARESVILLANUEVA, R. O. Growth, photosynthetic and respiratory responses to sub-lethal copper concentrations in Scenedesmus incrassatulus (Chlorophyceae). Chemosphere, v. 67, p. 2274- 2281, 2007.

REDDY G. N.; PRASAD, M. N. V. Heavy metal binding proteins/ peptides: Occurrence, structure, synthesis and functions: A review. Environ. expl Bot., v. 30, p. 251-264, 1990.

RENGER, R. H.; SCHREIBER, M. Practical applications of fluorimetric methods to algae and higher plant research. In: GOVINDJEE, A. M.; FORK, D. C. (Ed.). Light emission by plants and bacteria. New York: Academic Press, 1986. p. 587-619.

SINGH, V. P. Toxic metal cadmium: phytotoxicity and tolerance in plants. In: TRIVEDY, R. K. (Ed.). Advances in environmental science technology. New Delhi: Ashish Publication House, 1995. p. 225-256.

SOLISIO, C.; LODI, A.; SOLETTO, D.; CONVERTI, A. Cadmium biosorption on Spirulina platensis biomass. Bioresource Technol., v. 99, p. 5933-5937, 2008.

VALLEE, B. L.; AULD, D. S. Zinc coordination, function and structure of zinc enzymes and other proteins. Biochemistry., v. 29, p. 5647- 5659, 1990.

(Manuscript received 20 March 2010; revised 05 May 2010; accepted 13 July 2010) 